\title{
Using Ductus Venous Blood Flow Waveform as a Clinical Biomarker for the Detection of Aneuploidies-A Meta Analysis
}

\author{
Yibing $\mathrm{Ge}^{1}$, Lili Xia ${ }^{2 \#}$, Eugene $\mathrm{Chao}^{3^{*}}$ \\ ${ }^{1}$ Special Inspection Section of Anhui Military Hospital of Armed Police Force, \\ Hefei, Anhui Province, 230000, China; \\ ${ }^{2}$ Department of Ultrasound, Tongling People's Hospital, Tongling, Anhui \\ Province, 244000, China; \\ ${ }^{3}$ Duncan Neurological Research Institute, Houston, Texas, 77030, USA. \\ \# These authors contributed equally to this work.
}

*Correspondence: Eugene Chao, Duncan Neurological Research Institute, Houston, Texas, 77030, USA, Email: eugene.chao@bcm.edu.

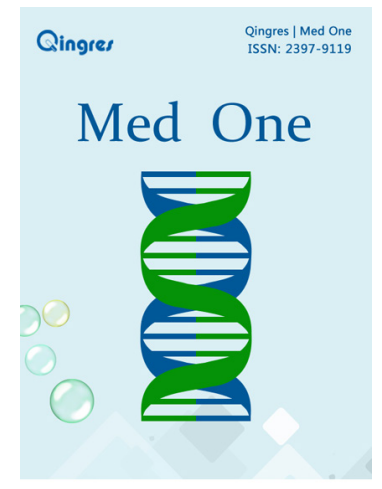

http://mo.qingres.com

\section{GOPEN ACCESS}

DOI: 10.20900/mo.20170017

Received: May 18, 2017

Accepted: July 20, 2017

Published: August 25, 2017

Copyright: $\odot 2017$ Cain et al. This is an open access article distributed under the terms of the Creative Commons Attribution License, which permits unrestricted use, distribution, and reproduction in any medium, provided the original author and source are credited.

\section{ABSTRACT}

Background: Ductus venosus (DV) Doppler has been suggested as a biomarker for the early screening of fetal aneuploidy. However, results from different studies are not always consistent. The aim of this study is to investigate the relationship between DV and fetal aneuploidy by systematically reviewing the published literature and performing a meta-analysis.

Methods: DV-Aneuploidy relationship data were extracted from previous publications, including 35,122 pregnant women. Among these, 613 fetuses had aneuploidy, 1522 had abnormal DV, and 382 had both abnormal DV and aneuploidy. Literature search was performed using PubMed Central, Medline, RePORTER and Elsevier Full-text Articles.

Results: Results from random-effects model showed that DV and aneuploidy are strongly correlated (Log odds ratio: 3.860.35, p-value $<1 \mathrm{e}-324)$. However, significant between-study variance was observed (I-Squared $=90.2 ;$-value $<2.29 \mathrm{e}-14$ ), suggesting that DV-Aneuploidy relationship is susceptible to multiple influence factors. However, multiple linear regression analysis suggested that the influence factors may not include maternal age, data age and sample size ( $p$-value > $0.27)$.

Conclusion: This study shows that abnormal DV is significantly associated with the incidence of aneuploidies, supporting the use of DV as a clinical maker for fetal aneuploidy screening. Further study will explore the influence factors for DV-Aneuploidy relationship that lead to variations among different sample groups.

Keywords: Ductus venosus; Chromosomal abnormalities; Fetal aneuploidy; Random model; Multiple linear regression model 


\section{INTRODUCTION}

Aneuploidy is the presence of an abnormal number of chromosomes in a cell, e.g., a human cell with 45 or 47 chromosomes instead of the normal number $46^{[1]}$. An extra or missing chromosome is a common cause of genetic disorders, including some human birth defects ${ }^{[2]}$. Aneuploidy is a major cause of perinatal morbidity and mortality, highlighting the importance of early detection. The first trimester (11 to 13 week) scan is now widely accepted as an important component of early screening for aneuploidy, structural defects and preeclampsia. Based on early screening results, patients can be triaged into early follow-up and possible amniocentesis at 14 to 16 weeks, or an anatomic survey at 18 to 20 weeks.

In the first trimester, ductus venosus (DV) can be easily identified by color Doppler, and DV waveform can be obtained by pulsed Doppler. Previous studies suggested that abnormal Doppler flow patterns of the DV are associated with an increased risk of fetal aneuploidy ${ }^{[3]}$. Moreover, extensive studies have demonstrated that abnormal flow in this vessel is associated with an increased risk for cardiac defects and other adverse pregnancy outcomes linked to chromosome abnormalities ${ }^{[4-6]}$.

Other studies suggested that the combined screening of nuchal translucency (NT) and DV can improve the detection rate of aneuploidies. Mavrides et al. found that the combined screening increases the sensitivity of Down syndrome detection to $94 \%$ and decreases the likelihood ratio of a negative test to $0.08^{[7]}$. Furthermore, abnormal DV increases the risk of cardiac defects ${ }^{[8]}$ in fetuses with NT above the 95th percentile, and may increase the risk in fetuses with normal $\mathrm{NT}^{[9]}$. These previous studies have built a solid background for fetal aneuploidy research, which can be leveraged for the discovery and evaluation of DV-Aneuploidy relationship.
However, the DV-Aneuploidy co-occurrence from different individual studies varies largely. As a result, it is difficult to draw a solid conclusion as to what degree DV can help in aneuploidy screening. Therefore, we performed this meta-analysis to provide an overall estimation of the log odds ratio (LOR) of aneuploidy in case of the DV, and evaluate the variance among studies.

\section{METHODS AND MATERIALS}

\subsection{Data screening}

A literature search was performed covering all up-to-date literatures from PubMed Central, Medline, RePORTER and Elsevier Full-text Article. First, 'ductus venosus' was used as keyword for searching, and 1,951 articles were identified. Further filter criteria included: 1) screening occurred in first trimester; 2) studies included relationship between DV and one or more aneuploidy: trisomy 21, trisomy 18 , trisomy 13 , Turner syndrome, triploidy and sex chromosome aneuploidies; 3 ) all required data were available: total number of samples; samples with DV abnormality; samples with aneuploidy, and samples with both DV abnormality and aneuploidy. In total, nine studies matched all the selection criteria and were thus included in the meta-analysis ${ }^{[6,10-17]}$.

The total pregnancy sample included in this study was 35,122 , including $613(1.75 \%)$ aneuploidy cases, 1,522 (4.42\%) abnormal DV, and 382 (62.32 $\%)$ with both aneuploidy and abnormal DV blood flow, as shown in Table 1. Maternal age at the time of ultrasound examination was over 30 years old (Range: 32.138 .5 ), and data age (current year -collection date) was from 1 to 19 years (1998 to 2016).

\subsection{Meta-analysis models}

Both fixed-effect model and random-effects model

Table 1. Studies reporting on the incidence of abnormal flow in the ductus venosus in the first trimester in chromosomal abnormalities

\begin{tabular}{lccccccc}
\hline Study Name & $\begin{array}{c}\text { Data } \\
\text { age }\end{array}$ & $\begin{array}{c}\text { Group 1 } \\
\text { total Num }\end{array}$ & $\begin{array}{c}\text { Case 1 } \\
\text {-aneuploidy }\end{array}$ & $\begin{array}{c}\text { Case 2 total } \\
\text { dv Num }\end{array}$ & $\begin{array}{c}\text { Case both } \\
\text { aneuploidy with } \\
\text { dv Num }\end{array}$ & $\begin{array}{c}\text { Racial } \\
\text { regions }\end{array}$ & $\begin{array}{c}\text { Maternal Age } \\
\text { (median) }\end{array}$ \\
\hline $\begin{array}{l}\text { Matias et al., } \\
1998^{[10]}\end{array}$ & 19 & 486 & 63 & 70 & 57 & $\begin{array}{c}\text { UK and } \\
\text { Portugal }\end{array}$ & 36 \\
$\begin{array}{l}\text { Antolin et al., } \\
2001^{[11]}\end{array}$ & 16 & 1371 & 20 & 78 & 14 & Spain & 35
\end{tabular}




\begin{tabular}{|c|c|c|c|c|c|c|c|}
\hline $\begin{array}{l}\text { Murta et al., } \\
2002^{[12]}\end{array}$ & 15 & 372 & 29 & 34 & 27 & Brazil & 34 \\
\hline $\begin{array}{l}\text { Zoppi et al., } \\
2002^{[13]}\end{array}$ & 15 & 325 & 34 & 61 & 23 & Italy & 35 \\
\hline $\begin{array}{l}\text { Borrell et al., } \\
2003^{[14]}\end{array}$ & 14 & 3382 & 133 & 222 & 60 & Spain & 36 \\
\hline $\begin{array}{l}\text { Toyama et al., } \\
2004^{[15]}\end{array}$ & 13 & 10971097 & 22 & 84 & 15 & Brazil & 32.1 \\
\hline $\begin{array}{l}\text { Maiz et al., } \\
2009^{[6]}\end{array}$ & 8 & 19800 & 186 & 747 & 119 & Mixed & 34.5 \\
\hline $\begin{array}{l}\text { Stressig et al., } \\
2011^{[16]}\end{array}$ & 6 & 3648 & 35 & 65 & 5 & Germany & 38.1 \\
\hline $\begin{array}{l}\text { Wagner et al., } \\
2016^{[17]}\end{array}$ & 1 & 4641 & 91 & 161 & 62 & Germany & 38.5 \\
\hline Total & & 35122 & 613 & 1522 & 382 & & \\
\hline
\end{tabular}

were used to study the effect size of the nine previous studies. The LOR of aneuploidy in the presence/absence of DV were taken as effect size in this study. Results from both models were compared and reported. The heterogeneity of the metaanalysis was analyzed to study the variance within and between the nine studies.

\subsection{Multiple linear regression analysis}

Multiple linear regression (MLR) model was employed to study the possible influence of three factors on DV-Aneuploidy relation: maternal age, data age and sample size.

\section{RESULTS}

\subsection{Meta-analysis results}

Results from the random-effects and fixed-effect models are described in Table 2, including effect size related statistics of nine studies and the metaanalysis results. The $p$-values from both metaanalysis models are all smaller than 1E-324, suggesting that there is significant association between DV blood flow and aneuploidy. Statistics from heterogeneity analysis of random-effects include: $Q$ value of 81.64 , I-Squared of 90.20 and $\mathrm{p}$-value of $2.29 \mathrm{E}-14$. These results suggest that the between study variance account for $90.20 \%$ of the total variance, and the probability that the different studies share a common effect size is only $2.29 \mathrm{E}-14$. Therefore, the random-effects model is more suitable for this study. However, the results of fixed-effect model are also presented for comparison purposes.

Table 2. The effects of two models for aneuploidy s with abnormal DV findings

\begin{tabular}{|c|c|c|c|c|c|c|c|c|}
\hline Study Name & $\begin{array}{l}\text { Effect } \\
\text { Size }\end{array}$ & $\begin{array}{l}\text { Lower Limit } \\
\text { of } 95 \% \mathrm{Cl}\end{array}$ & $\begin{array}{l}\text { Upper Limit } \\
\text { of } 95 \% \mathrm{Cl}\end{array}$ & Z_Value & $\begin{array}{l}\text { pValue (one } \\
\text { tailed) }\end{array}$ & $\begin{array}{l}\text { pValue (two } \\
\text { tailed) }\end{array}$ & $\begin{array}{l}\text { Weight } \\
\text { Fixed }\end{array}$ & $\begin{array}{l}\text { Weight_ } \\
\text { Random }\end{array}$ \\
\hline $\begin{array}{l}\text { Matias et al., } \\
1998^{[10]}\end{array}$ & 5.70 & 4.70 & 6.71 & 11.11 & $<1 \mathrm{E}-324$ & $<1 \mathrm{E}-324$ & 3.79 & 0.86 \\
\hline $\begin{array}{l}\text { Antolin et al., } \\
2001^{[11]}\end{array}$ & 3.85 & 2.86 & 4.84 & 7.63 & 1.19E-14 & $2.38 \mathrm{E}-14$ & 3.93 & 0.87 \\
\hline $\begin{array}{l}\text { Murta et al., } \\
2002^{[12]}\end{array}$ & 6.47 & 4.85 & 8.09 & 7.83 & 2.33E-15 & 4.66E-15 & 1.46 & 0.63 \\
\hline $\begin{array}{l}\text { Zoppi et al., } \\
2002^{[13]}\end{array}$ & 2.63 & 1.84 & 3.43 & 6.49 & $4.30 \mathrm{E}-11$ & $8.60 \mathrm{E}-11$ & 6.07 & 0.94 \\
\hline
\end{tabular}




\begin{tabular}{|c|c|c|c|c|c|c|c|c|}
\hline $\begin{array}{l}\text { Borrell et al., } \\
2003^{[14]}\end{array}$ & 2.75 & 2.37 & 3.13 & 14.33 & $<1 \mathrm{E}-324$ & $<1 \mathrm{E}-324$ & 27.13 & 1.07 \\
\hline $\begin{array}{l}\text { Toyama et al., } \\
2004^{[15]}\end{array}$ & 3.44 & 2.51 & 4.37 & 7.26 & $2.0 \mathrm{E}-13$ & $3.99 \mathrm{E}-13$ & 4.44 & 0.89 \\
\hline $\begin{array}{l}\text { Maiz et al., } \\
2009^{[6]}\end{array}$ & 3.98 & 3.67 & 4.29 & 25.21 & $<1 \mathrm{E}-324$ & $<1 E-324$ & 40.04 & 1.08 \\
\hline $\begin{array}{l}\text { Stressig et al., } \\
2011^{[16]}\end{array}$ & 2.29 & 1.31 & 3.27 & 4.58 & 2.37E-06 & 4.73E-06 & 4.00 & 0.87 \\
\hline $\begin{array}{l}\text { Wagner et al., } \\
2016^{[17]}\end{array}$ & 4.57 & 4.08 & 5.05 & 18.50 & $<1 \mathrm{E}-324$ & $<1 \mathrm{E}-324$ & 16.41 & 1.04 \\
\hline Fixed Model & 3.69 & 3.50 & 3.88 & 38.21 & $<1 \mathrm{E}-324$ & $<1 \mathrm{E}-324$ & & \\
\hline Random Model & 3.86 & 3.18 & 4.54 & 11.10 & $<1 \mathrm{E}-324$ & $<1 \mathrm{E}-324$ & & \\
\hline
\end{tabular}

To compare the results from the two metaanalysis models, the mean LOR, its $95 \%$ confidence interval $(\mathrm{Cl})$, and the weights used in each metaanalysis model are presented in Fig. 1. Although the fixed model and random model generate similar effect size (3.69 vs. 3.86), the $95 \% \mathrm{Cl}$ of the fixed model is much smaller, leading to bigger Z-value than that of random model (38.21 vs. 11.10). The differences between the two models are also demonstrated in the weights, as shown in Fig. 1. The larger sample-sized studies tend to gain relatively smaller weights in the random model than that in the fixed-effect model.

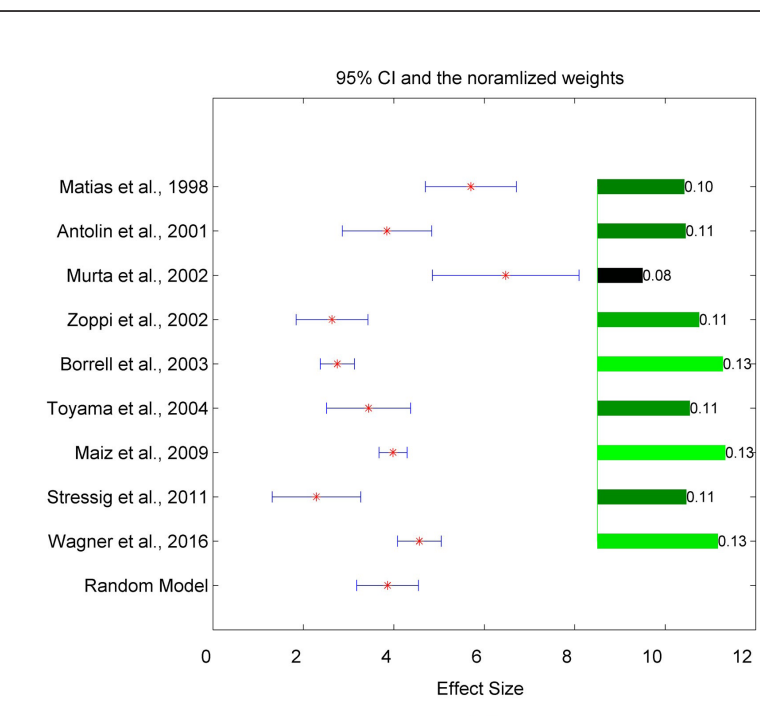

(a)

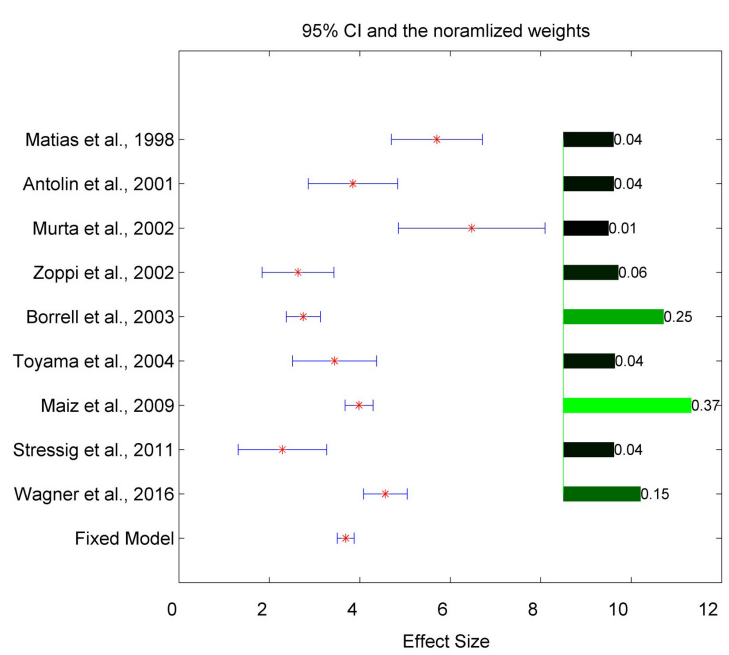

(b)

Fig.1 Two models for aneuploidy with abnormal DV findings. (a) Random-effects model; (b) Fixed-effect model. 


\subsection{MLR analysis results}

Results from the multiple linear regression model show that the three tested factors, maternal age, data age and total number of cases, are not significantly associated with the DV-aneuploidy relations, as shown in Table 3 . Moreover, Table 3 shows that the effective sizes of different studies are far from a constant vector ( $p$-value $=0.499)$, which is consistent with heterogeneity analysis from the random-effects model that significant variance exist between different studies.

Table 3. Multiple linear regression for data characters

\begin{tabular}{|c|c|c|c|c|}
\hline & Constant & Data age & Sample size & Maternal age (median) \\
\hline Beta & 3.9171 & 0.0581 & 0.0000 & -0.0185 \\
\hline Low Limit & -36.0629 & -0.3427 & -0.0003 & -1.0423 \\
\hline Up Limit & 43.8970 & 0.4588 & 0.0003 & 1.0054 \\
\hline$p$-value & 0.4990 & 0.2714 & 0.4839 & 0.5272 \\
\hline
\end{tabular}

\section{DISCUSSION}

Although many studies have been conducted revealing associations between aneuploidy and DV, results vary, questioning the effectiveness of using DV to screen for aneuploidies. This metaanalysis not only provides an overall estimation of the mean LOR distribution for the presence/absence of aneuploidy in case of the presence/absence of DV, but also demonstrates the significant variance between different studies.

In this study, 613 out of the total 35,122 samples were diagnosed with fetal aneuploidy. As shown in Table 1, abnormal DV flows were observed in $62.32 \%$ of the aneuploidy cases. Meta-analysis results (see Table 2) suggested that abnormal DV are significantly related to aneuploidy (LOR: $3.86 \pm$ 0.35 , p-value < 1e-324). However, we also observed significant between-study variance (I-Squared $=90.2 ; p$-value $<2.29 \mathrm{e}-14)$. The $p$-value for the regression coefficient of the constant term of 0.499 indicates that, for two given studies, the probability is about $50 \%$ for them to present significantly different mean LOR. These results suggest that influential factors exist for the DV-aneuploidy relations, leading to significant variances between different sample groups.
However, MLR results showed that maternal age, data age and sample size, are not significantly associated with the DV-aneuploidy relations ( $p$-value $>0.27$ ). These results provide us the following information. 1) DV is suitable for the aneuploidy screen for pregnant women of all ages; 2) The DVaneuploidy relation has been consistent during the past 19 years for a given sample group; 3 ) The LOR for a given sample group is generally stable regardless of sample size. While these results suggest the robustness of the DV-aneuploidy relationship, this also indicates that there are other influential factors that lead to the variance of the effect size of different studies, which are worthy of further study.

Moreover, only 24.61 of the 1,552 DV abnormal cases also had aneuploidy. Therefore, DV alone is not sufficient for the screening of aneuploidy. This is consistent with previous studies that addressed the integration of nuchal translucency (NT) and DV in the screening of aneuploidies ${ }^{[7-8]}$.

\section{CONCLUSION}

The results of this study demonstrate that fetal aneuploidy is significantly associated with first- 
trimester abnormal DV, supporting the rationality of using DV as a clinical factor for the early detection of aneuploidies. However, using DV alone is not sufficient for aneuploidy screening. MLR results presented significant between-study variances, indicating there were influential factors behind the scene of each unique study, which is worth of further exploration. However, MLR analysis results from this study suggested that maternal age, data age and sample size may not be influential factors for the DVaneuploidy association.

\section{CONFLICT OF INTERESTS}

The authors claim no conflict of interests.

\section{REFERENCES}

1. Santaguida S, Amon A. Short- and long-term effects of chromosome mis-segregation and aneuploidy. Nat Rev Mol Cell Biol. 2015; 16(8): 473-485.

2. Sen S. Aneuploidy and cancer. Curr Opin Oncol. 2000; 12(1): 82-88.

3. Florjański J, Fuchs T, Zimmer M, Homola W, Pomorski M, Blok D. The role of ductus venosus Doppler flow in the diagnosis of chromosomal abnormalities during the first trimester of pregnancy. Adv Clin Exp Med. 2013; 22(3): 395401.

4. Oh C, Harman C, Baschat AA. Abnormal firsttrimester ductus venosus blood flow: a risk factor for adverse outcome in fetuses with normal nuchal translucency. Ultrasound Obstet Gynecol. 2007; 30: 192-196.

5. Maiz N, Valencia C, Emmanuel EE, Staboulidou I, Nicolaides KH. Screening for adverse pregnancy outcome by ductus venosus Doppler at $11-13+6$ weeks of gestation. Obstet Gynecol. 2008; 112: 598-605.

6. Maiz N, Staboulidou I, Leal AM, Minekawa R, Nicolaides KH. Ductus venosus Doppler at 11 to 13 weeks of gestation in the prediction of outcome in twin pregnancies. Obstet Gynecol. 2009; 113: 860-865.

7. Mavrides E, Sairam S, Hollis B, Thilaganathan B. Screening for aneuploidy in the first trimester by assessment of blood flow in the ductus venosus. BJOG. 2002; 109(9):1015-1019.

8. Geipel A, Gembruch U. [Screening performance of first trimester nuchal translucency, ductus venosus blood flow and tricuspid regurgitation for cardiac defects]. Z Geburtshilfe Neonatol. 2012; 216(4): 157-161.

9. Maiz N, Nicolaides KH. Ductus venosus in the first trimester: contribution to screening of chromosomal, cardiac defects and monochorionic twin complications. Fetal Diagn Ther. 2010; 28(2): 65-71.

10. Matias A, Gomes C, Flack N, Montenegro N, Nicolaides $\mathrm{KH}$. Screening for chromosomal abnormalities at 10-14 weeks: the role of ductus venosus blood flow. Ultrasound Obstet Gynecol. 1998; 12(6): 380-384.

11. Antolin E, Comas C, Torrents M, Munoz A, Figueras F, Echevarria M, Cararach M, Carrera JM. The role of ductus venosus bloodflow assessment in screening for chromosomal abnormalities at 10-16 weeks of gestation. Ultrasound Obstet Gynecol. 2001; 17: 295-300.

12. Murta CG, Moron AF, Avila MA, Weiner CP. Application of ductus venosus Doppler velocimetry for the detection of fetal aneuploidyin the first trimester of pregnancy. Fetal Diagn Ther. 2002; 17: 308-314.

13. Zoppi MA, Putzolu M, Ibba RM, Floris M, Monni G. First-trimester ductus venosus velocimetry in relation to nuchal translucency thickness and fetal karyotype. Fetal Diagn Ther. 2002; 17: 5257.

14. Borrell A, Martinez JM, Seres A, Borobio V, Cararach V, Fortuny A. Ductus venosus assessment at the time of nuchal translucency measurement in the detection of fetal aneuploidy. Prenat Diagn. 2003; 23: 921-926.

15. Toyama JM, Brizot ML, Liao AW, Lopes LM, Nomura RM, Saldanha FA, Zugaib M. Ductus venosus blood flow assessment at 11 to 14 weeks of gestation and fetal outcome. Ultrasound Obstet Gynecol. 2004; 23(4): 341345.

16. Stressig R, Kozlowski P, Froehlich S, Siegmann HJ, Hammer R, Blumenstock G, Kagan KO. Assessment of the ductus venosus, tricuspid blood flow and the nasal bone in secondtrimester screening for trisomy 21 . Ultrasound Obstet Gynecol. 2011; 37(4): 444-449.

17. Wagner P, Sonek J, Hoopmann M, Abele H, Kagan KO. First-trimester screening for trisomies 18 and 13 , triploidy and Turner syndrome by detailed early anomaly scan. Ultrasound Obstet Gynecol. 2016; 48(4): 446-451. 